\title{
RESEARCH
}

Open Access

\section{Serum electrolyte balance and antioxidant status of broiler chickens fed diets containing varied levels of monosodium glutamate (MSG)}

Olumuyiwa Joseph Olarotimi ${ }^{1,2}$

\begin{abstract}
Background: The effects of dietary monosodium glutamate (MSG) on the serum electrolyte balance and antioxidant status of broiler chickens were assessed. In five replicates, a total of 300-day-old unsexed Abor-acre broilers were randomly allotted into six treatment groups containing varied levels of MSG at 0.00, 0.25, 0.50, 0.75, 1.00 , and $1.25 \mathrm{~g} / \mathrm{kg}$ diet, respectively. The experimental birds were fed ad libitum with clean water provided regularly for a period of 8 weeks. On the 56th day of the experiment, five birds per replicate were randomly selected and fasted overnight. Blood samples were collected from the wing veins for serum electrolytes analyses. Serum electrolytes such as sodium $\left(\mathrm{Na}^{+}\right)$, potassium $\left(\mathrm{K}^{+}\right)$, and chloride $\left(\mathrm{Cl}^{-}\right)$as well as oxidative stress indicators assay such as total antioxidant capacity (T-OAC), malondialdehyde (MDA), superoxide dismutase (SOD), and glutathione peroxidase (GSH-Px) activities were determined using standard procedures. Data collected were subjected to analysis of variance at $a=0.05$.

Results: The results revealed that MSG inclusion above $0.75 \mathrm{~g} / \mathrm{kg}$ diet significantly $(P<0.05)$ increased the serum $\mathrm{Na}^{+}$and $\mathrm{K}^{+}$concentrations of the broiler chickens when compared with birds on the control diet, whereas the serum $\mathrm{Cl}^{-}$concentration significantly $(P<0.05)$ decreased from $0.50 \mathrm{~g} \mathrm{MSG} / \mathrm{kg}$ diet inclusion level. On the other hand, MSG inclusion level above $0.50 \mathrm{~g} / \mathrm{kg}$ diet increased the serum MDA concentration (from $2.60 \pm 0.01$ to $4.60 \pm$ $0.00)$ of the birds while serum GSH-Px and T-AOC concentrations significantly $(P<0.05)$ reduced from $170 \pm 0.28$ to $120 \pm 0.26$ and $3.30 \pm 0.01$ to $1.70 \pm 0.01$, respectively.
\end{abstract}

Conclusion: Inclusion level above $0.50 \mathrm{~g} / \mathrm{kg}$ diet could adversely offset normal physiological processes in broilers by predisposing them to renal dysfunction, coronary problem, and oxidative stress.

Keywords: Broiler, Electrolytes, Antioxidant, Serum, Monosodium glutamate

\footnotetext{
Correspondence: olarotimioj@futa.edu.ng

'Department of Animal Science, Adekunle Ajasin University, Akungba Akoko,

Nigeria

2Department of Animal production and Health, The Federal University of

Technology Akure, Akure, Nigeria
}

\section{Springer Open}

(c) The Author(s). 2020 Open Access This article is licensed under a Creative Commons Attribution 4.0 International License, which permits use, sharing, adaptation, distribution and reproduction in any medium or format, as long as you give appropriate credit to the original author(s) and the source, provide a link to the Creative Commons licence, and indicate if changes were made. The images or other third party material in this article are included in the article's Creative Commons licence, unless indicated otherwise in a credit line to the material. If material is not included in the article's Creative Commons licence and your intended use is not permitted by statutory regulation or exceeds the permitted use, you will need to obtain permission directly from the copyright holder. To view a copy of this licence, visit http://creativecommons.org/licenses/by/4.0/. 


\section{Introduction}

Feed palatability and acceptability is a feed factor that should not be compromised while formulating diets for broiler chickens to meet the animals' requirement. Several reasons might be responsible for the nonpalatability of feed. Quality deterioration of raw materials, especially, the by-products such as rice and maize (rice and maize offals) stored over a long period of time will produce flavors and odors that are not acceptable by the birds. This will constitute a key factor in poor feed performance. To some extent, varying manufacturing processes, premixes having off-flavor carriers, and bases and fats present in materials such as groundnut cake may equally contribute to feed non-palatability if allowed to go rancid.

Flavor enhancing additives could be of great benefit in accessing the inherent nutrients of resultant feeds. MSG is regarded as an additive which can enhance the palatability of food (Khalil and Khedr 2016). However, the excessive dosage of MSG administration has been implicated in conferring varying negative effects on animals (Eweka 2007). Diniz et al. (2004) reported that chronic administration of MSG induced oxidative stress in the tissues of young rats. Further study has also that MSG-induced hyperglycemia caused oxidative stress in the kidney through the formation of free radicals and altered the antioxidant reactions mediated by reactive oxygen species (ROS) scavenging enzymes (Koya et al. 2003). Furthermore, chronic oral MSG intake in rats was equally reported to have led to changes in antioxidant systems and renal markers including lipid peroxidation byproducts (Paul et al. 2012). For serum electrolytes, MSG-treated rats were reported to record significantly higher levels of serum creatinine, potassium, and sodium compared to the controls (Sharma et al. 2013). Ilegbedion et al. (2013) documented elevations in serum $\mathrm{K}^{+}$, $\mathrm{Na}^{+}, \mathrm{Cl}^{-}$, and $\mathrm{Ca}^{2+}$ concentrations of female adult Wistar rats administered with a high dose of MSG.

The objective of this study was to evaluate the oxidative stress induced by MSG in the broiler chickens as well as its influence on serum electrolyte balance so as to establish acceptable and safe inclusion levels in broiler diets to enhance the palatability for optimum feed performance.

\section{Materials and methods}

\section{Experimental design and animals}

A total of 300-day-old, unsexed Arbor-acre broiler chicks was used for the experiment which lasted for 8 weeks at the poultry unit of the livestock section of the Teaching and Research Farm, The Federal University of Technology, Akure. On arrival of the chicks, they were weighed and assigned to the 6 dietary treatment groups: $\mathrm{A}, \mathrm{B}, \mathrm{C}, \mathrm{D}, \mathrm{E}$, and F containing 0.00 (control), 0.25, 0.50,
$0.75,1.00$, and $1.25 \mathrm{~g} \mathrm{MSG} / \mathrm{kg}$ diet, respectively, in a completely randomized design. Each treatment was replicated five times with 10 birds per replicate. The birds were fed with broiler starter (Table 1) and finisher (Table 2) diets ad libitum from 0 to 4 weeks and 4 to 8 weeks, respectively.

\section{Blood sampling}

At the end of the experiment ( 8 weeks), from each replicate, 5 birds per group were randomly selected for blood sampling. The birds were fasted overnight and blood samples were collected from the wing veins into dry clean centrifuged glass tubes without any coagulant to separate the serum for determination of serum electrolytes and antioxidant status indicators. Blood samples were left for $15 \mathrm{~min}$ at room temperature, and then, the tubes were centrifuged for $10 \mathrm{~min}$ at $3000 \mathrm{rpm}$ to obtain clean supernatant serum. The harvested serum samples were kept frozen at $-20^{\circ} \mathrm{C}$ until the determination of serum GSH-Px, T-AOC, MDA, SOD, $\mathrm{Na}^{+}, \mathrm{K}^{+}$, and $\mathrm{Cl}^{-}$ concentrations.

\section{Serum electrolyte measurements}

Serum electrolytes $\left(\mathrm{Na}^{+}, \mathrm{K}^{+}\right.$, and $\left.\mathrm{Cl}^{-}\right)$were analyzed by auto analyzer (Kodak Ektachem; Eastman Kodak Company, Rochester, New York).

\section{Sodium ion $\left(\mathrm{Na}^{+}\right)$}

The serum $\mathrm{Na}^{+}$concentration was evaluated as described by Terri and Sesin (1958). Sodium ion was calculated using the following formula:

$$
\mathrm{Na}^{+}(\mathrm{mEq} / \mathrm{L})=\frac{\text { Abs.blank }- \text { Abs.S }}{\text { Abs.blank }- \text { Abs.Std }} \times \text { Conc.Std }
$$

Abs $=$ absorbance

$\mathrm{S}=$ sample

STD $=$ standard

\section{Potassium ion $\left(K^{+}\right)$}

The serum $\mathrm{K}^{+}$concentration was determined using the method Terri and Sesin (1958).

$$
\begin{aligned}
& \text { Concentration of } \mathrm{K}^{+} \text {in sample }(\mathrm{mEq} / \mathrm{L}) \\
& =\frac{\text { Absorbance of sample } \times \text { conc.of standard }}{\text { Absorbance of standard }}
\end{aligned}
$$

Potassium standard : equivalent to $4 \mathrm{mEq} / \mathrm{L}$

\section{Chloride ion $\left(\mathrm{Cl}^{-}\right)$}

The serum $\mathrm{Cl}^{-}$concentration was evaluated by the method described by Skeggs and Hochstrasser (1964). 
Table 1 Ingredient composition of the experimental starter diets $(\mathrm{kg})$

\begin{tabular}{|c|c|c|c|c|c|c|}
\hline \multirow[t]{2}{*}{ Ingredients } & \multirow[t]{2}{*}{$A(0.00)$} & \multicolumn{4}{|c|}{ Inclusion level of MSG (kg) } & \multirow[b]{2}{*}{$F(1.25)$} \\
\hline & & $\mathrm{B}(0.25)$ & $C(0.50)$ & $\mathrm{D}(0.75)$ & $E(1.00)$ & \\
\hline Maize & 430.00 & 430.00 & 430.00 & 430.00 & 430.00 & 430.00 \\
\hline Soybean meal & 200.00 & 200.00 & 200.00 & 200.00 & 200.00 & 200.00 \\
\hline Groundnut cake & 170.00 & 170.00 & 170.00 & 170.00 & 170.00 & 170.00 \\
\hline Fish meal $(72 \% C P)$ & 20.00 & 20.00 & 20.00 & 20.00 & 20.00 & 20.00 \\
\hline Rice bran & 60.00 & 60.00 & 60.00 & 60.00 & 60.00 & 60.00 \\
\hline Maize offal & 80.00 & 80.00 & 80.00 & 80.00 & 80.00 & 80.00 \\
\hline Bone meal & 19.00 & 19.00 & 19.00 & 19.00 & 19.00 & 19.00 \\
\hline Limestone & 12.25 & 12.00 & 11.75 & 11.50 & 11.25 & 11.00 \\
\hline Salt & 3.05 & 3.05 & 3.05 & 3.05 & 3.05 & 3.05 \\
\hline MSG & 0.00 & 0.25 & 0.50 & 0.75 & 1.00 & 1.25 \\
\hline Lysine & 1.00 & 1.00 & 1.00 & 1.00 & 1.00 & 1.00 \\
\hline Methionine & 2.20 & 2.20 & 2.20 & 2.20 & 2.20 & 2.20 \\
\hline Broiler premix & 2.50 & 2.50 & 2.50 & 2.50 & 2.50 & 2.50 \\
\hline Total & 1000.00 & 1000.00 & 1000.00 & 1000.00 & 1000.00 & 1000.00 \\
\hline \multicolumn{7}{|l|}{ Calculated nutrients } \\
\hline ME (Kcal/Kg) & 2913.36 & 2913.36 & 2913.36 & 2913.36 & 2913.36 & 2913.36 \\
\hline Crude protein (\%) & 23.13 & 23.13 & 23.13 & 23.13 & 23.13 & 23.13 \\
\hline Calcium (\%) & 1.34 & 1.33 & 1.32 & 1.31 & 1.31 & 1.30 \\
\hline Phosphorus (\%) & 0.52 & 0.52 & 0.52 & 0.52 & 0.52 & 0.52 \\
\hline Lysine (\%) & 1.19 & 1.19 & 1.19 & 1.19 & 1.19 & 1.19 \\
\hline Methionine (\%) & 0.56 & 0.56 & 0.56 & 0.56 & 0.56 & 0.56 \\
\hline Crude fiber (\%) & 4.48 & 4.48 & 4.48 & 4.48 & 4.48 & 4.48 \\
\hline Fat (\%) & 5.24 & 5.24 & 5.24 & 5.24 & 5.24 & 5.24 \\
\hline
\end{tabular}

${ }^{*}$ Composition of premix: $2.5 \mathrm{~kg}$ of premix contains Vit. A (10000000 iu), Vit. D3 (2500000 iu), Vit. E (12000 iu), Vit. B1 (2000 mg), niacin (15000 mg), Vit.B6 (1500 mg), Vit. B12 (10 mg), Vit. K3 $(2000 \mathrm{mg})$, biotin $(20 \mathrm{mg})$, folic acid $(600 \mathrm{mg})$, panthothenic acid $(7000 \mathrm{mg})$, chlorine chloride $(150000 \mathrm{mg})$, manganese $(80000 \mathrm{mg})$, iron $(40000 \mathrm{mg})$, copper $(10 \mathrm{mg})$, zinc $(60000 \mathrm{mg})$, selenium $(150 \mathrm{mg})$, iodine $(1000 \mathrm{mg})$, magnesium $(100 \mathrm{mg})$, ethoxyquine $(500 \mathrm{~g})$, and BHT (700 g)

Concentration of $\mathrm{Cl}^{-}$in sample $(\mathrm{mEq} / \mathrm{L})$ $=\frac{\text { Absorbance of sample } \times \text { conc.of standard }}{\text { Absorbance of standard }}$

Chloride calibrator : sodium chloride : $100 \mathrm{mEq} / \mathrm{L}$

\section{Antioxidant status indicator measurement Malondialdehyde (MDA)}

The determination of the serum MDA was done by thiobarbituric acid (TBA) assay method as described by Baliga et al. (2018). The absorbance is determined as follows:

MDA content $(\mathrm{nmol} / \mathrm{mL})$

$=\frac{\text { Abs.sample-Abs.control }}{\text { Abs.standard }- \text { Abs.blank }} \times$ concentration of standard $(\mathrm{nmol} / \mathrm{ml})$

\section{Glutathione peroxidase}

The serum glutathione peroxidase enzyme activity was measured using the method described by Flohe and Gunzler (1984). GSH-P $x$ concentration was calculated as $\mathrm{U} / \mathrm{l}$ of hemolysate (the hemolysate was prepared by adding equal volumes of the reagent into normal salinewashed packed red cells and mixing for $5 \mathrm{~min}$ ) $=8412 \times$ $\Delta \mathrm{A} 340 \mathrm{~nm} / \mathrm{min}$

\section{Superoxide dismutase}

The serum superoxide dismutase (SOD) activity was determined as highlighted by Oyanagui (1984).

$$
\text { SOD content }(\mathrm{nmol} / \mathrm{mL})=\frac{\mathrm{A}_{2}-\mathrm{A}_{1}}{3}
$$

\section{Total antioxidant concentration}

The serum total antioxidant concentration was determined using colorimetric method as described by 
Table 2 Ingredient composition of the experimental finisher diets (kg)

\begin{tabular}{|c|c|c|c|c|c|c|}
\hline \multirow[t]{2}{*}{ Ingredients } & \multirow[t]{2}{*}{$A(0.00)$} & \multicolumn{4}{|c|}{ Inclusion level of MSG (kg) } & \multirow[b]{2}{*}{$F(1.25)$} \\
\hline & & $B(0.25)$ & $C(0.50)$ & $\mathrm{D}(0.75)$ & $E(1.00)$ & \\
\hline Maize & 430.00 & 430.00 & 430.00 & 430.00 & 430.00 & 430.00 \\
\hline Soybean meal & 107.00 & 107.00 & 107.00 & 107.00 & 107.00 & 107.00 \\
\hline Groundnut cake & 105.00 & 105.00 & 105.00 & 105.00 & 105.00 & 105.00 \\
\hline Rice bran & 130.00 & 130.00 & 130.00 & 130.00 & 130.00 & 130.00 \\
\hline Full fat soya & 40.00 & 40.00 & 40.00 & 40.00 & 40.00 & 40.00 \\
\hline Sorghum & 45.00 & 45.00 & 45.00 & 45.00 & 45.00 & 45.00 \\
\hline Maize offal & 100.00 & 100.00 & 100.00 & 100.00 & 100.00 & 100.00 \\
\hline Bone meal & 18.00 & 18.00 & 18.00 & 18.00 & 18.00 & 18.00 \\
\hline Limestone & 13.00 & 12.75 & 12.50 & 12.25 & 12.00 & 11.75 \\
\hline Salt & 2.50 & 2.50 & 2.50 & 2.50 & 2.50 & 2.50 \\
\hline MSG & 0.00 & 0.25 & 0.50 & 0.75 & 1.00 & 1.25 \\
\hline Lysine & 4.00 & 4.00 & 4.00 & 4.00 & 4.00 & 4.00 \\
\hline Methionine & 3.00 & 3.00 & 3.00 & 3.00 & 3.00 & 3.00 \\
\hline Broiler premix & 2.50 & 2.50 & 2.50 & 2.50 & 2.50 & 2.50 \\
\hline Total & 1000.00 & 1000.00 & 1000.00 & 1000.00 & 1000.00 & 1000.00 \\
\hline \multicolumn{7}{|l|}{ Calculated nutrients } \\
\hline ME (Kcal/Kg) & 2961.16 & 2961.16 & 2961.16 & 2961.16 & 2961.16 & 2961.16 \\
\hline Crude protein (\%) & 18.33 & 18.33 & 18.33 & 18.33 & 18.33 & 18.33 \\
\hline Calcium (\%) & 1.19 & 1.18 & 1.17 & 1.16 & 1.16 & 1.15 \\
\hline Phosphorus (\%) & 0.47 & 0.47 & 0.47 & 0.47 & 0.47 & 0.47 \\
\hline Lysine (\%) & 1.10 & 1.10 & 1.10 & 1.10 & 1.10 & 1.10 \\
\hline Methionine (\%) & 0.55 & 0.55 & 0.55 & 0.55 & 0.55 & 0.55 \\
\hline Crude fiber (\%) & 4.82 & 4.82 & 4.82 & 4.82 & 4.82 & 4.82 \\
\hline Fat (\%) & 6.40 & 6.40 & 6.40 & 6.40 & 6.40 & 6.40 \\
\hline
\end{tabular}

Lussignoli et al. (1999). Total antioxidant conc. was calculated as follows:

$$
\text { Factor }=\frac{\text { Conc.of standard }}{(\Delta \mathrm{A} \text { blank }-\Delta \mathrm{A} \text { standard })}
$$

$$
\mathrm{mmol} / \mathrm{l}=\text { Factor } \times(\Delta \text { A Blank }-\Delta \text { A Sample })
$$

\section{Statistical analysis}

All experimental data obtained were subjected to oneway analysis of variance (ANOVA) using GraphPad Prism, software version 6.01 (2012). Significant differences between the treatment means were compared using Tukey's honestly significant difference (HSD) option of the same software at $5 \%$ level of significance.

\section{Results}

The birds on diets containing 1.00 and $1.25 \mathrm{~g}$ MSG $/ \mathrm{kg}$ are statistically $(P>0.05)$ similar and significantly $(P<$ 0.05 ) higher in serum $\mathrm{Na}^{+}$concentrations (Table 3) when compared with the birds on other diets. Furthermore, the inclusion of 0.75 to $1.25 \mathrm{~g}$ MSG $/ \mathrm{kg}$ diet significantly $(P<0.05)$ raised the serum $\mathrm{K}^{+}$concentrations (Table 3) of the chickens while the inclusion of MSG above $0.50 \mathrm{~g} / \mathrm{kg}$ diet significantly $(P<0.05)$ depressed the serum $\mathrm{Cl}^{-}$concentrations (Table 3) of the broiler chickens. Furthermore, the inclusion of MSG in excess of $0.50 \mathrm{~g} / \mathrm{kg}$ diet significant $(P<0.05)$ lowered the serum concentrations of both GSH-Px and T-AOC (Table 4) while the serum MDA concentrations (Table 4) were significantly $(P<0.05)$ elevated among the birds fed diets containing above $0.75 \mathrm{~g}$ MSG $/ \mathrm{kg}$ with those on diet $1.25 \mathrm{~g} \mathrm{MSG} / \mathrm{kg}$ recording the highest value. However, the MSG inclusion levels employed in the present study did not significantly $(P>0.05)$ affect the serum SOD 
Table 3 Serum electrolyte of the broilers fed diets with different levels of MSG

\begin{tabular}{llllllll}
\hline Parameters & $\mathrm{A}(0.00)$ & $\mathrm{B}(0.25)$ & $\mathrm{C}(0.50)$ & $\mathrm{D}(0.75)$ & $\mathrm{E}(1.00)$ & $\mathrm{F}(1.25)$ & $P$ value \\
\hline $\mathrm{Na}^{+}(\mathrm{mEq} / \mathrm{L})$ & $136.24 \pm 0.33^{\mathrm{bc}}$ & $135.99 \pm 0.30^{\mathrm{bc}}$ & $137.95 \pm 0.30^{\mathrm{b}}$ & $138.00 \pm 0.62^{\mathrm{b}}$ & $149.16 \pm 0.33^{\mathrm{a}}$ & $149.99 \pm 0.58^{\mathrm{a}}$ & $<0.0001^{*}$ \\
$\mathrm{~K}^{+}(\mathrm{mEq} / \mathrm{L})$ & $3.51 \pm 0.06^{\mathrm{c}}$ & $3.75 .01^{\mathrm{bc}}$ & $3.70 \pm 0.04^{\mathrm{bc}}$ & $4.00 \pm 0.03^{\mathrm{b}}$ & $5.57 \pm 0.02^{\mathrm{ab}}$ & $5.90 \pm 0.02^{\mathrm{a}}$ & $<0.0001^{*}$ \\
$\mathrm{Cl}^{-}(\mathrm{mEq} / \mathrm{L})$ & $105.03 \pm 0.28^{\mathrm{a}}$ & $103.00 \pm 0.19^{\mathrm{ab}}$ & $98.00 \pm 0.29^{\mathrm{ab}}$ & $93.13 \pm 0.18^{\mathrm{c}}$ & $86.00 \pm 0.29^{c d}$ & $80.97 \pm 0.30^{\mathrm{d}}$ & $0.0346^{*}$ \\
\hline
\end{tabular}

Values are means \pm SEM, means in a row without common superscripts are significantly $(P<0.05)$ different. Level of significance $=$ ns $($ not significant) $=P>0.05$; ${ }^{*} P<0.05$, sodium $\left(\mathrm{Na}^{+}\right)$; potassium $\left(\mathrm{K}^{+}\right)$; chloride $\left(\mathrm{Cl}^{-}\right)$, MSG levels in $\mathrm{g} / \mathrm{kg}$ diet

(Table 4) activities across all the treatment diets and the control though a dose-dependent decrease was observed in response to an elevation in MSG inclusion levels.

\section{Discussions}

\section{Serum electrolytes}

The body of animals including poultry contains a large variety of ions, or electrolytes, which perform a variety of functions. The ions in the blood plasma play important roles in osmotic balance that regulates the movement of water between cells and their environment. In the present study, the elevated blood $\mathrm{Na}^{+}$and $\mathrm{K}^{+}$levels observed among the chickens on diets containing 1.00 and $1.25 \mathrm{~g}$ MSG/kg were above the reference values (135-145 mEq/L for $\mathrm{Na}^{+}$and 3.5-5.0 mEq/L for $\mathrm{K}^{+}$(Jain 1993)) for chickens apart from being significantly different from those on the control diets. This is indicative that a high dose of MSG in broiler diets above $0.50 \mathrm{~g} / \mathrm{kg}$ could result in both hypernatremia and hyperkalemia. The results of this finding agreed with the report of Ilegbedion et al. (2013) who documented an elevation in the blood $\mathrm{Na}^{+}$and $\mathrm{K}^{+}$levels of Wistar rats fed a high dose of MSG. This was also in line with the finding of Sharma et al. (2013) who observed that high-dose MSG treatment in adult rats significantly elevated the levels of serum creatinine, potassium, and sodium compared when compared with the controls. Peterson and Levi (2013), however, opined that hyperkalemia is an indication of renal failure since renal excretion is the common route of potassium elimination. Hypertensive rats were also reported to have an increased serum $\mathrm{Na}^{+}$ concentration (Ilegbedion et al. 2013). Hence, feeding broiler chickens MSG above a tolerable level of $0.50 \mathrm{~g} / \mathrm{kg}$ diet could predispose them to renal dysfunction as well as coronary problem. On the other hand, birds on diets containing $0.75 \mathrm{~g} \mathrm{MSG} / \mathrm{kg}$ and above recorded hypochloremia. This is lower-than-normal blood chloride levels. It was also suggestive of defective renal tubular absorption. Hypochloremia could also result from vomiting, diarrhea, and metabolic acidosis. Symptoms of hypochloremia are similar to those of hyponatremia and could result in general weakness.

\section{Serum antioxidant status}

It is a common knowledge that oxidative stress leads to break down of the immune system, precipitates radicals, and causes severe disease situations (Jimoh et al. 2018). Though the body has a variety of defense mechanisms against the damaging effects of free radicals, oxidative stress induced by dietary source could limit the ability of self-defense, hence leading to cellular damage. The results obtained in the present study revealed that dietary MSG had significant effects on antioxidant and peroxide formation in broiler chickens. Lipid peroxidations, measured as MDA levels, in the broilers were significantly increased in response to increasing levels of MSG inclusion. There were no significant differences among the birds on diets containing 0.25 and $0.50 \mathrm{~g}$ MSG $/ \mathrm{kg}$ and those on the control diet. The significant decrease observed above this tolerable level of inclusion could be attributed to the significant decrease observed in the total T-AOC of the birds fed MSG above $0.50 \mathrm{~g} / \mathrm{kg}$ diet inclusion rate. An increase in the levels of MDA favors oxidative stress while an increase in $\mathrm{T}$-AOC protects against free radicals and peroxides; there is always an inverse relationship between lipid peroxidation and antioxidant capacity (Jimoh et al. 2018). This result supported the claim by Bertolin et al. (2011) that MSG is a very reactive substance and induced lipid peroxidation, leading to the formation of reactive substances of low molecular weight, such as MDA. Farombi and Onyema (2006) equally recorded an increased formation of MDA in the

Table 4 Antioxidant status of the broilers fed diets with different levels of MSG

\begin{tabular}{llllllll}
\hline Parameters & A (0.00) & B (0.25) & C (0.50) & D (0.75) & E (1.00) & $F(1.25)$ & $P$ value \\
\hline GSH-Px $(\mu \mathrm{mol} / \mathrm{ml})$ & $210 \pm 0.29^{\mathrm{a}}$ & $200 \pm 0.21^{\mathrm{ab}}$ & $199 \pm 0.29^{\mathrm{ab}}$ & $170 \pm 0.28^{\mathrm{b}}$ & $129.33 \pm 0.10^{\mathrm{c}}$ & $120 \pm 0.26^{\mathrm{d}}$ & $<0.0001^{*}$ \\
SOD $(\mu \mathrm{mol} / \mathrm{ml})$ & $120 \pm 0.43$ & $120 \pm 0.26$ & $119 \pm 0.29$ & $113.67 \pm 0.24$ & $111.67 \pm 0.21$ & $110 \pm 0.31$ & $0.2282^{\mathrm{ns}}$ \\
T-AOC $(\mu \mathrm{mol} / \mathrm{ml})$ & $5.63 \pm 0.00^{\mathrm{a}}$ & $4.00 \pm 0.00^{\mathrm{ab}}$ & $3.95 \pm 0.03^{\mathrm{ab}}$ & $3.30 \pm 0.01^{\mathrm{b}}$ & $2.40 \pm 0.01^{\mathrm{c}}$ & $1.70 \pm 0.01^{\mathrm{d}}$ & $<0.0001^{*}$ \\
MDA $(\mathrm{nmol} / \mathrm{ml})$ & $1.90 \pm 0.03^{\mathrm{c}}$ & $2.03 \pm 0.02^{\mathrm{c}}$ & $2.60 \pm 0.01^{\mathrm{bc}}$ & $3.93 \pm 0.00^{\mathrm{b}}$ & $3.93 \pm 0.03^{\mathrm{b}}$ & $4.60 \pm 0.00^{\mathrm{a}}$ & $0.0003^{*}$ \\
\hline
\end{tabular}

Values are means \pm SEM, means in a row without common superscripts are significantly $(P<0.05)$ different. Level of significance $=$ ns (not significant) $=P>0.05$; ${ }^{*} P<0.05$, glutathione peroxidase (GSH-Px); total antioxidant activity (T-AOC); malondialdehyde (MDA); superoxide dismutase (SOD); MSG levels in g/kg diet 
liver and brain of Wistar rats administered MSG intraperitoneally at $4 \mathrm{mg} / \mathrm{g}$ of body weight.

In the present study, antioxidant enzyme activity assayed revealed that superoxide SOD which is the first line of defense was negatively influenced by varied levels of MSG inclusion. Functionally, SOD converts superoxides to hydrogen peroxides $\left(\mathrm{H}_{2} \mathrm{O}_{2}\right)$ while GSH-Px converts $\mathrm{H}_{2} \mathrm{O}_{2}$ to water and gaseous oxygen (Egbuonu and Ejike 2017). The decreased SOD activity observed among the birds fed $0.75 \mathrm{~g}$ MSG/kg diet and above, though not significant, confirmed increased involvement of SOD in antioxidant defense response following MSG-induced oxidative stress and this was in consonance with the position of (Manal and Nawal 2012). The depletion of GSH-Px observed among the broilers fed $0.75 \mathrm{~g}$ MSG $/ \mathrm{kg}$ diet and above was indicative of its role as a second line of antioxidant defense mechanism. The decreased GSHPx observed in this study as MSG inclusion increases was in consistent with the findings of (Egbuonu and Ejike 2017). A decrease in GSH-Px activity induced by MSG consumption had also been explained to favor lipogenesis by increasing the level of glutamine (Kushwaha and Bharti 2015). GSH-Px uses glutathione as a substrate to catalyze the conversion of $\mathrm{H}_{2} \mathrm{O}_{2}$ to water and gaseous oxygen, thereby protecting mammalian cells against oxidative stress (Singh and Ahluwalia 2012). It is, therefore, suggestive that low activity of this enzyme may render the tissue more susceptible to lipid peroxidation damage.

\section{Conclusion}

The present study established that the inclusion of dietary MSG up to $0.50 \mathrm{~g} / \mathrm{kg}$ diet did not confer any deleterious effects on broiler chickens as far as serum electrolyte balance and antioxidant status are concerned. However, the inclusion level above $0.50 \mathrm{~g} / \mathrm{kg}$ dietinduced oxidative stress and depletion of the total antioxidant activities.

\section{Abbreviations \\ $\mathrm{Cl}^{-}$: Chloride; GSH-Px: Glutathione peroxidase; $\mathrm{K}^{+}$: Potassium; MDA: Malondialdehyde; MSG: Monosodium glutamate; $\mathrm{Na}^{+}$: Sodium; ROS: Reactive oxygen species; SOD: Superoxide dismutase; T-OAC: Total antioxidant capacity}

\section{Acknowledgements}

The author is grateful to the management and staff of the Nutrition Laboratory of Animal production and Health for their assistance during the bench work.

\section{Author's contributions}

OJO designed, carried out the field work, and supervised the study; carried out the statistical analysis; and wrote the manuscript. The author read and approved the final manuscript.

\section{Funding}

This work did not receive any specific grant from any funding agency in the public, commercial, or not-for-profit sector.

\section{Availability of data and materials}

The datasets used and/or analyzed during the current study are available from the corresponding author on reasonable request.

Ethics approval and consent to participate

The study was undertaken with approval from the institutional ethics committee for care and use of animal for research of the host institution.

Consent for publication

Not applicable

\section{Competing interests}

The author declares that he has no competing interests.

Received: 18 November 2019 Accepted: 8 June 2020

Published online: 18 June 2020

\section{References}

Baliga S, Chaudhary M, Bhat S, Bhansali P, Agrawal A, Gundawar S (2018) Estimation of malondialdehyde levels in serum and saliva of children affected with sickle cell anemia. J Indian Soc Pedod Prev Dent 36:43-47

Bertolin TE, Farias D, Guarienti C, Petry FTS, Colla LM, Costa JAV (2011) Antioxidant effect of phycocyanin on oxidative stress induced with monosodium glutamate in rats. Braz Arch Biol Technol 54(4):733-738

Diniz YS, Fernandes AA, Campos KE, Mani F, Ribas BO, Novelli EL (2004) Toxicity of hyper caloric diet and monosodium glutamate: oxidative stress and metabolic shifting in hepatic tissue. Food Chem Toxicol 42:319-325

Egbuonu ACC, Ejike GE (2017) Effect of pulverized Mangifera indica (Mango) seed kernel on monosodium glutamate-intoxicated rats' serum antioxidant capacity, brain function and histology. EC Pharmacol Toxicol 4(6):228-243

Eweka AO (2007) Histological studies of the effects of monosodium glutamate on the cerebellum of adult wistar rats. J Neurosci Neurosurg Psychiat 8:2-7

Farombi EO, Onyema OO (2006) Monosodium glutamate-induced oxidative damage and genotoxicity in the rat: modulatory role of vitamin $\mathrm{C}$, vitamin $\mathrm{E}$ and guercetin. Hum Exp Toxicol 125:251-259

Flohe L, Gunzler WA (1984) Assays of glutathione peroxidase. Methods Enzymol 105:114-21.32

llegbedion IG, Onyije FM, Digba KA (2013) Evaluation of MSG on electrolyte balance and histology of gastroesophageal mucosa. M-E J Sci Res 18(2):163167

Jain NC (1993) Essential of veterinary hematology. Lea\& Febiger, Philadelphia

Jimoh OA, Ihejirika UG, Balogun AS, Adelani SA, Okanlawon OO (2018) Antioxidant status and serology of laying pullets fed diets supplemented with mistletoe leaf meal. Nig J Anim Sci 20(1):52-60

Khalil RM, Khedr NF (2016) Curcumin protects against monosodium glutamate neurotoxicity and decreasing NMDA2B and mGluR5 expression in rat hippocampus. Neurosig 24:81-87

Koya D, Hayashi K, Kitada M, Kashiwagi A, Kikkawa R, Haneda M (2003) Effects of antioxidants in diabetes-induced oxidative stress in the glomeruli of diabetic rats. J Am Soc Nephrol 14:S250-S253

Kushwaha VB, Bharti G (2015) Effect of monosodium glutamate (MSG) administration on some antioxidant enzymes in muscles of adult male mice. J Appl Biosci 41(1):54-56

Lussignoli S, Fraccaroli M, Andrioli G, Brocco G, Bellavite P (1999) A microplatebased colorimetric assay of the total peroxyl radical trapping capability of human plasma. Anal Biochem 269(1):38-44

Manal ST, Nawal A (2012) Adverse effects of monosodium glutamate on liver and kidney functions in adult rats and potential protective effect of vitamins $C$ and E. Food Nutr Sci 3(5):651-659

Oyanagui $Y$ (1984) Reevaluation of assay methods and establishment of kit for superoxide dismutase activity. Anal Biochem 142(2):290-296

Paul MV, Abhilash M, Varghese MV, Alex M, Harikumaran Nair R (2012) Protective effects of alpha-tocopherol against oxidative stress related to nephrotoxicity by monosodium glutamate in rats. Toxicol Mech Methods 22:625-630. https://doi.org/10.3109/15376516.2012.714008

Peterson LN, Levi M (2003) Disorders of Potassium Metabolism. In: Schrier RW, ed Renal and Electrolyte Disorders. 6th ed. Philadelphia: Lippincott Williams \& Wilkins. pp. 171-215.

Sharma A, Prasongwattana V, Cha'on U, Selmi C et al (2013) Monosodium glutamate (MSG) consumption is associated with urolithiasis and urinary tract 
obstruction in rats. PLoS One 8(9):e75546. https://doi.org/10.3109/15376516. 2012.714008

Singh K, Ahluwalia P (2012) Effect of monosodium glutamate on lipid peroxidation and certain antioxidant enzymes in cardiac tissue of alcoholic adult male mice. J Cardio Dis Res 3:12-18

Skeggs LT, Hochstrasser HC (1964) Thiocyanate (colometric) method of chloride estimation. J Clin Chem 10:918

Terri AE, Sesin PG (1958) Determination of serum potassium by using sodium tetraphenylboro method. Am J Clin Pathol 29(1):86-90

\section{Publisher's Note}

Springer Nature remains neutral with regard to jurisdictional claims in published maps and institutional affiliations.

\section{Submit your manuscript to a SpringerOpen ${ }^{\mathcal{O}}$} journal and benefit from:

- Convenient online submission

- Rigorous peer review

- Open access: articles freely available online

High visibility within the field

- Retaining the copyright to your article

Submit your next manuscript at $\boldsymbol{\nabla}$ springeropen.com 